\title{
Urgences
}

\section{L'année perdue...}

\section{Marie-Rose Comeau}

Numéro 13, mars 1986

Éclats d'atelier

URI : https://id.erudit.org/iderudit/025212ar

DOI : https://doi.org/10.7202/025212ar

Aller au sommaire du numéro

Éditeur(s)

Urgences

ISSN

0226-9554 (imprimé)

1927-3924 (numérique)

Découvrir la revue

Citer ce document

Comeau, M.-R. (1986). L'année perdue... Urgences, (13), 34-34.

https://doi.org/10.7202/025212ar

Ce document est protégé par la loi sur le droit d'auteur. L'utilisation des services d'Érudit (y compris la reproduction) est assujettie à sa politique d'utilisation que vous pouvez consulter en ligne.

https://apropos.erudit.org/fr/usagers/politique-dutilisation/
Cet article est diffusé et préservé par Érudit.

Érudit est un consortium interuniversitaire sans but lucratif composé de l’Université de Montréal, l'Université Laval et l'Université du Québec à Montréal. Il a pour mission la promotion et la valorisation de la recherche. https://www.erudit.org/fr/ 


\section{Marie-Rose Comeau}

L'année perdue du chien qui m'apparaît comme la scène et l'échec, agités mais lestes dans les trous, se balance comme un Janus aphone, borgne et secret, avec des faces qui contempient le recto, sans regarder vers le verso, au signe de l'astre, des bouts de l'heure au bruit du repos.

Le second temps comme nous le mesurons se lovera au double coeur éperdu, plongé, de l'abîme se projetant à la pente et au décan joyeux, sidéré. Les pères sèmeront le doute, étendront le tissu du geste, porteront les pâtes et les pains, les mèneront hors de la magie qui torture, mélange, éreinte, rêvasse, et regagne le néant, le songe aux échos de l'enfer maudit, reclus. Abritons-nous hors de l'éveil étroit, délit et fuite épique, doute, fable, sujet de génie de la scène divine qui séduira. Le clown dessine confus, s'obstine pourri, calcine violet, le signe.

La sueur se congèle comme Roméo sans la Julia, mélange la chose et le genre, dans un faible bruit animant la folie creuse et perdue par l'image docile d'une plume lucide sur des riens, des idées, des peurs hautes, des cimes qui se dérobent devant la peste des chats nobles et grands, que le recul nous livrera avec avril. 